\title{
The usage of the battle simulation in History and Geography classes: the case study of the Battle of Nagyharsány, Hungary
}

\author{
Róbert Szabó \\ University of Pécs, Doctoral School of Earth Sciences
}

\begin{abstract}
In our fast-changing world, the attitude of the young generations has changed and it requires new methods and ideas in every level of the education system. Teachers must adapt to the challenges of the 21 st century. The paradigm of Problem Based Learning could be one solution. Using PBL can help to keep up the motivation and improve the pupil's competences. To develop student's competences my paper expresses such type of battle simulation. Teachers can use it even on an average Geography and History class. The central topic of this educational project plan is the Battle of Nagyharsány (the Kingdom of Hungary, 1687). With the help of instructions, maps, and historical sources the students can imagine the original environmental, social and diplomatic circumstances of that historical era through the battle in mention. They have to make decisions as the Christian generals did at that time: moving or not; finding the best place to attack the enemy; etc. The aim is the same as 350 years ago: defeat the Ottoman army somehow and reconquest Hungary from the occupation. Finally, the participating pupils can develop collaborative problemsolving, empathical and science literacy skills.
\end{abstract}

Keywords: Problem Based Learning, competences, collaborative problemsolving, History and Geography, role play 